How to cite this work: García-Hernández, M., Ivars-Baidal, J., \& Mendoza de Miguel, S. (2019). Overtourism in urban destinations: the myth of smart solutions. Boletín de la Asociación de Geógrafos Españoles, 83, 2830, 1-38. http://dx.doi.org/10.21138/bage.2830

\title{
Overtourism in urban destinations: the myth of smart solutions
}

Sobrecarga turística (overtourism) en espacios urbanos:

el mito de las soluciones inteligentes

\author{
María García-Hernández \\ mgarciah@ucm.es \\ Departamento de Geografía \\ Universidad Complutense de Madrid (Spain) \\ Josep Ivars-Baidal \\ josep.ivars@ua.es \\ Instituto Universitario de Investigaciones Turísticas \\ Universidad de Alicante (Spain)

\section{Sofía Mendoza de Miguel} \\ smendo01@ucm.es \\ Departamento de Geografía \\ Universidad Complutense de Madrid (Spain)
}

\begin{abstract}
The rapid increase in urban tourism flows generates problems of tourist overcrowding and gives rise to important challenges for city management. Within this context, urban tourism planning is experiencing a convergence of new paradigms related to the so-called Smart Tourist Destinations (SD). Smart tourism and its operational level open up new avenues for intervention in the city
\end{abstract}


which can help to manage overtourism. Therefore, the objective of this study is to analyse the level of implementation of smart solutions in four Spanish destinations: Donostia-San Sebastián, Madrid, Málaga and Valencia. The methodology used combines the compilation of information on initiatives and measures found in public tourism planning documents with semi-structured interviews with those responsible for managing the Smart City strategy and the SD project. The results reveal that there is a gap between the SD approaches, the level of implementation of smart solutions and their operability in relation to the management of tourist overload. Almost no technological solutions have been developed to address this issue, which is barely perceived as a problem by local governments. However, the need to generate knowledge that is useful for managing tourist overload constitutes a challenge faced by a growing number of destinations.

Key words: overtourism; overcrowding; smart tourism; smart destinations; urban planning.

\section{Resumen}

El rápido aumento de los flujos de turismo urbano genera problemas de sobrecarga turística y plantea importantes retos para la gestión de la ciudad. En este escenario convergen a su vez nuevos paradigmas en la planificación del turismo relacionados con los llamados Destinos Turísticos Inteligentes (DTI). El turismo inteligente y su nivel operativo abren nuevas vías de intervención en la ciudad que pueden ayudar a gestionar la saturación turística. Por ello esta investigación tiene como objetivo analizar el nivel de implementación de soluciones inteligentes en cuatro destinos urbanos españoles: Donostia-San Sebastián, Madrid, Málaga y Valencia. La metodología empleada combina la recopilación documental de iniciativas y medidas recogidas en documentos de planificación turística con la realización de entrevistas semiestructuradas a los responsables de la estrategia Smart City y del proyecto DTI. Los resultados alcanzados permiten entrever un desfase entre los planteamientos del DTI, el nivel de implementación de soluciones inteligentes y su operatividad en relación con la gestión de la sobrecarga turística. Apenas existe desarrollo de soluciones aplicadas a este tema, escasamente percibido aún como problemático desde la administración local. No obstante, la necesidad de generar conocimiento útil para la gestión de la sobrecarga turística constituye un reto al que se enfrentan un número creciente de destinos.

Palabras clave: overtourism; sobrecarga turística; smart tourism; destinos turísticos inteligentes; planificación urbana. 


\section{Introduction}

The considerable increase in tourist inflows in cities is causing tourist overcrowding in certain destinations such as Venice, Barcelona or Amsterdam. The phenomenon has been widely reported in the media and has given rise to citizen movements denouncing the negative impacts of tourism in their neighbourhoods and calling for a better management of this activity. These processes are not new and have been seen in many destinations since tourism became a mass activity in the second half of the twentieth century, due to a confluence of well-known factors (economic growth, improvements in transport, international political stability, etc.). Hence, the analysis of the impacts of tourism since the 1960s and 1970s has addressed analogous concepts such as social and tourism carrying capacity (Mathieson \& Wall, 1982; O’Reilly, 1986) or conceptual models of tourist-resident interaction such as Doxey's Tourist Irritation Index (1975).

The novelty resides in the intensity of the phenomenon in certain spaces, in its public notoriety and in the level that conventional urban spaces are affected, as opposed to destinations highly specialised in tourism which are apparently better designed to accommodate considerable volumes of tourists. The term to define this phenomenon, and which is profusely used, is overtourism. Its use dates back to the beginning of the 2000s, although it became widespread later, in 2017 and 2018, as evidenced in the emergence of different documents promoted by international institutions (Dichter and Gloria, 2017; European Cities Marketing, 2018; Peeters et al., 2018; UNWTO, 2018), the recording of the term by the digital publication specialised in tourism and travel, Skift, and the first research studies on this topic (Koens et al. 2018; Milano, 2018; Milano et al., 2018).

The definitions of overtourism underline the impact of tourism on a destination, or on part of it, that negatively affects the quality of life perceived by the residents and/or the perceived quality of the visitors' experience (Goodwin, 2017; UNWTO, 2018). The excessive tourism pressure generates overcrowding which affects the well-being of residents and forces them to change their lifestyle (Milano et al., 2018). The controversial concept of tourismphobia has even been coined (Huete \& Mantecón, 2018; Milano, 2018). Furthermore, overcrowding generates an overload of the infrastructures and negatively affects local nature, culture and heritage (Dichter and Gloria, 2017). Peeters et al. (2018) compile the above definitions in order to emphasise that overtourism exceeds physical, ecological, social, economic, psychological and/or political capacity thresholds. 
However, it is not simple to establish the threshold that separates concentration from overload because the perception is not unanimous for all of the stakeholders involved. In some cases, crowds can even be seen as stimulating, as indicated by Tuan (1977) for certain events or beach destinations. An identical volume of tourists can generate overcrowding in one tourist space but not in another depending on the characteristics of the tourists and the destination itself. Therefore, an analysis of the local context is fundamental.

In any event, there is a broad consensus on associating overload with a deficient management of the destination when this field of public intervention is responsible for preventing and correcting it. Tourism policy directed at capturing demand in a framework of public-private collaboration has shown its incapacity to prevent and even less resolve a phenomenon that has become an urban problem which cannot be addressed with merely sectoral policies. In view of the predominance of the neoliberal approaches of tourism policy, the need for a greater public leadership has arisen with an emphasis on its regulatory role (Koens et al., 2018).

This study forms part of the need to analyse and propose new approaches to planning and tourism management to anticipate and correct overtourism processes (Joppe, 2019), particularly the smart city and destination approach. An approach that, theoretically, goes beyond the use of technological solutions, which, on their own, do not seem to be proving to be enough to prevent and resolve the problems derived from the overload (Koens et al., 2018; UNWTO, 2018). In this context, the research work carried out seeks to answer the following questions: Are Spanish cities that suffer from tourism pressure integrating solutions related to overtourism management into their smart city or smart tourism destination strategies? What scope do these solutions have? The study is interesting because, as indicated in the Observatorio para la Tranformación Digital de los Destinos Turísticos, there are already many potential solutions and public and private agents promoting the use of technology in tourist destinations. However, it is not clear which are the priority areas, which solutions contribute the most or which technologies are already functioning and can be used successfully on a local scale (Exceltur, 2019, p. 3). In addition, the literature review highlights the few reflections on the implementation of the smart city / tourism destination approach in destinations that suffer from overtourism. This literature is scarce perhaps because it is a complex and recent phenomenon.

The results of this study are presented in seven sections. After this introduction, there is a description of the methodology used in relation to the different objectives of the study. The third section analyses the origin and causes of overtourism as a problem that has arisen and the type 
of solutions proposed from a theoretical and applied point of view. The fourth section addresses how the smart approach fits with the challenges posed by the management of the overloading of tourist spaces. Point five reviews the smart solutions proposed by institutional literature, those implemented in other European cities and those derived from the aid received from state programmes in Spain. The sixth section studies the state of the question in four Spanish cities (Donostia-San Sebastián, Madrid, Málaga and Valencia) and the conclusions are drawn in the final section.

The results of the study show that issues related to overtourism in four Spanish destinations still have little impact on urban tourism planning in general and on smart city and smart destination strategies in particular. Although the smart destination approach can be useful for the management of overtourism, urban managers have their suspicions about the high expectations created around technological solutions. In this sense, the results indicate that although these smart and technological solutions are progressively improving the urban and tourist management of cities, their application is still weak and there is a gap between the smart destination approaches, the level of implementation of smart solutions and their operability in relation to the management of tourist overload.

\section{Objectives and methodology}

The overall objective of this paper is to analyse smart solutions related to the management of overtourism in order to assess to what extent these solutions are integrated into smart city or smart destination strategies in Spain. The first part of the article (sections 3 and 4) has the specific objective of presenting a brief state of the art about the concept of overtourism and the relationships generated with the planning and smart tourism management approaches on a theoretical level. It is based on the documentary analysis of secondary sources (scientific production and other grey literature documents).

The results of the research carried out are presented in sections 5 and 6. Section 5 seeks to investigate and systematise the smart or technological solutions proposed as being useful for the management of overtourism on three levels:

1. The discourse of official bodies and other institutions or organisations that, on an international or national level, generate or contribute to generating states of opinion on the subject. 
2. The compared reference of initiatives developed in other European cities with tourist overcrowding problems.

3. The technological solutions proposed in the applications for public funding in Spain.

This section aims to offer an overview of technological/smart solutions and overtourism from a comparative perspective (Spanish cities that participate in publicly funded programmes and international experiences). It is also based on the analysis of secondary documentary sources: reports and publications of public bodies and different organisations, documents related to the projects financed in the two rounds of the Plan Nacional de Ciudades Inteligentes (National Smart Cities Plan) (2015-2017) and in the Plan Nacional de Territorios Inteligentes (National Smart Territories Plan) (2017-2020) in its "Smart Tourist Destinations" category and diagnostic reports and improvement plans of the municipalities involved in the "Smart Tourist Destinations" Programme (hereafter SD), promoted by SEGITTUR (a public body devoted to tourism technologies and innovation attached to the Ministry of Industry, Energy and Tourism).

Section 6 presents the empirical work. Four cities with a similar tourism profile that are involved in the development of smart city strategies, with high rates of recent tourism growth and symptoms of occasional and/or localised tourist overload have been selected: Donostia-San Sebastián, Madrid, Málaga and Valencia. As this is a qualitative investigation, the sample selection does not meet the criteria of statistical representativeness (probabilistic sampling). This is an intentional sample that includes a selection of cases that are "significant" for the research objective according to the authors' criteria.

The objective of this section is to study the scope of the implementation of smart destination strategies, smart cities strategies and technological solutions from the point of view of the managers of theses cities. In order to fulfil this objective the following sources and methods were used: secondary sources (data on the current situation of tourism, tourism planning documents, guideline plans of smart cities and SD projects) and primary sources, a series of semi-structured interviews with those responsible for implementing the SD project or smart city strategy. Overall, a total of seven interviews were conducted between the months of March and June 2019 in accordance with a script of contents divided into the following blocks:

1. Information about the SD project and/or smart city project (launch, trajectory, planning documents, departments involved...).

2. Opinion about the SD concept and its implementation. 
3. Types of technological solutions implemented (approach, scope, objectives, use by tourist, limitations...).

4. Perception of overtourism and solutions adopted (scope of the phenomenon, associated problems, type of measures implemented...).

The institutions associated with the interviewees are the following: Turismo de San Sebastián, S.A., Fomento de San Sebastián, S.A., Madrid Destino Turismo, Cultura y Negocio, S.A., Área de Turismo y Promoción de la Ciudad y Economía Productiva del Ayuntamiento de Málaga (in this case there were two interviewees), Oficina de Ciudad Inteligente (Smart City Office, City Council of Valencia) and Fundación Turismo de Valencia. All the people interviewed, considered as key informants, had a technical profile and held managerial positions in the above-mentioned institutions.

In Section 6, the data collected has been transversally processed giving rise to a paper that, in all four case studies, reviews: a) the state of opinion with respect to the growth of tourist inflows and the perception of overtourism from the perspective of smart strategy and city tourism managers; b) the proposals made in the tourism planning documents of these cities with regard to this matter; c) the SD and smart city strategies and, finally, d) the technological solutions developed in recent years.

\section{Overtourism in urban areas: triggers, consequences and policy responses}

The concentration of tourists in certain destinations is inseparable from mass tourism. At least since the 1960s massification has been observed in all types of tourist spaces, particularly in those with seasonal peaks such as beach destinations. Iconic spaces and/or attractions in cities have also suffered from tourist congestion and its negative effects. This is the case of the excess visitors in Venice, which has been widely discussed for decades. However, today massification has reached a greater level of intensity; it has extended to more destinations, it is causing acute functional and socio-economic transformations in the urban fabric and is giving rise to greater social discontent.

\subsection{The catalysing factors of overtourism in urban-areas}

A series of factors of change have led to this situation. Dodds and Butler (2019) identify them by using three converging spheres, two of the socio-economic environment and one specific sphere of the destination space: 
1. Agents of growth: increase in the number of tourists and the emergence of new segments. Economic growth implies an increase in available income for travelling, favoured by demographic change that brings about a higher propensity to travel among the younger generations (millennials and generation $X$ ) and older generations due to the increase in life expectancy (Dichter \& Gloria, 2017).

2. Technology applied to means of transport and tourist communication. With respect to transport, the technological evolution makes it easier to purchase cheaper, faster and safer trips both in the airline sector and cruises. The emergence of social networks has transformed both tourist communication and the behaviour of certain segments of travellers.

3. Power structures focused on tourism growth with a short-term perspective and local agents with different viewpoints regarding the effects of tourism.

To these three spheres it is necessary to add, as technology-based growth agents, the new business models such as the low-cost airlines, the lower cruise prices as a way to capture demand which is compensated by other revenue derived from additional services offered by the cruise liners (Navarro-Ruiz et al., 2019) or tourist accommodation marketed through platforms such as Airbnb or Homeaway. The supply of this type of accommodation has had a highly relevant impact, varying in accordance with two basic parameters identified by Sequera and Gil (2018): the type of accommodation (shared or professional) and the degree of territorial concentration or dispersion of the supply, where professional management (multi-owner) and concentration are usually predominant. Both of these factors intensify the turistification processes.

Adopting the metaphor of Francis (2019), these factors have arisen like a volcanic eruption which had been waiting to erupt for some time, with negative consequences on an urban, socioeconomic and tourism level. Furthermore, the future forecast for these factors does not paint a very promising picture due to a foreseeable intensification of tourist mobility in accordance with economic, socio-economic and technological dynamics (Yeoman, 2018).

\subsection{Impact and responses to a complex phenomenon}

Overtourism is a complex phenomenon with a multicausal origin that surpasses the boundaries of the tourism sphere. A sectoral view to diagnose and resolve the problem is clearly insufficient. It is a manifestation of the capitalist political economy, the causes of which need to be addressed (Fletcher, 2018) and where the dynamics of globalisation are reflected on a local scale. The systematic causes of this phenomenon lay outside the scope of this study. However, it is 
important to examine the interaction of different types of global and local factors (economic, social, cultural, political, technological, etc.) that generate tourist overload in order to correctly focus the planning and management proposals. In fact, this phenomenon is transforming the tourism policy in urban environments. As López Palomeque (2015) explains for the city of Barcelona, the overload processes justify moving away from sectoral promotion policies and towards considering tourism as a structural component of the city that requires a transversal approach. This has given rise to more restrictive measures of the tourism activity with progressive governments (Russo \& Scarnato, 2017).

The following table summarises the pressure indicators (that reveal situations of overload of different intensities), the impacts (whose origin is not exclusively attributable to tourism, a circumstance which complicates the diagnosing and identification of solutions) and the response measures. As it is a summary table, it is considerably simplified in terms of both the effects and the response policies. For example, touristification combined with other factors brings about an increase in the rental prices of housing, the transformation of the commercial fabric, the expulsion of residents, etc. Furthermore, the implementation of measures would require a very detailed description of public and private actions. This table only shows the response measures as the technologies used in the smart solutions are identified in Table 2.

When the impact of the overload is significant, citizen movements emerge against touristification (Milano and Mansilla, 2018) and the citizens' perception of tourism deteriorates, which is reflected in surveys and opinions in social networks. In turn, the quality of the tourist experience is lowered which is also visible in tourist satisfaction surveys and in comments on social networks. At this moment, overtourism has become a problem. 
Table 1. Summary of the indicators of pressure, impact and response measures to overtourism in urban spaces

\begin{tabular}{|c|c|c|}
\hline INDICATORS OF PRESSURE & IMPACT & RESPONSE MEASURES \\
\hline $\begin{array}{l}\text { - Density of tourist overnight } \\
\text { stays per inhabitant and per } \\
\text { unit of surface area } \\
\text { - Percentage of Airbnb and } \\
\text { Booking.com } \\
\text { accommodation of the total } \\
\text { - Percentage of tourism of } \\
\text { regional GDP } \\
\text { - Intensity of flights (flight } \\
\text { arrivals/number of residents) } \\
\text { - Closeness to the airport, } \\
\text { cruise port or Heritage Site } \\
\text { (UNESCO) }\end{array}$ & $\begin{array}{l}\text { - Touristification } \\
\text { (transformation of the } \\
\text { commercial fabric...) } \\
\text { - } \quad \text { Contribution to } \\
\text { gentrification } \\
\text { - Urban recentralisation } \\
\text { - Overcrowding and/or } \\
\text { privatisation of public } \\
\text { spaces } \\
\text { - Overcrowding of public } \\
\text { services (e.g. transport) } \\
\text { - Environmental pollution } \\
\text { (concentration of gases or } \\
\text { acoustic pollution) }\end{array}$ & 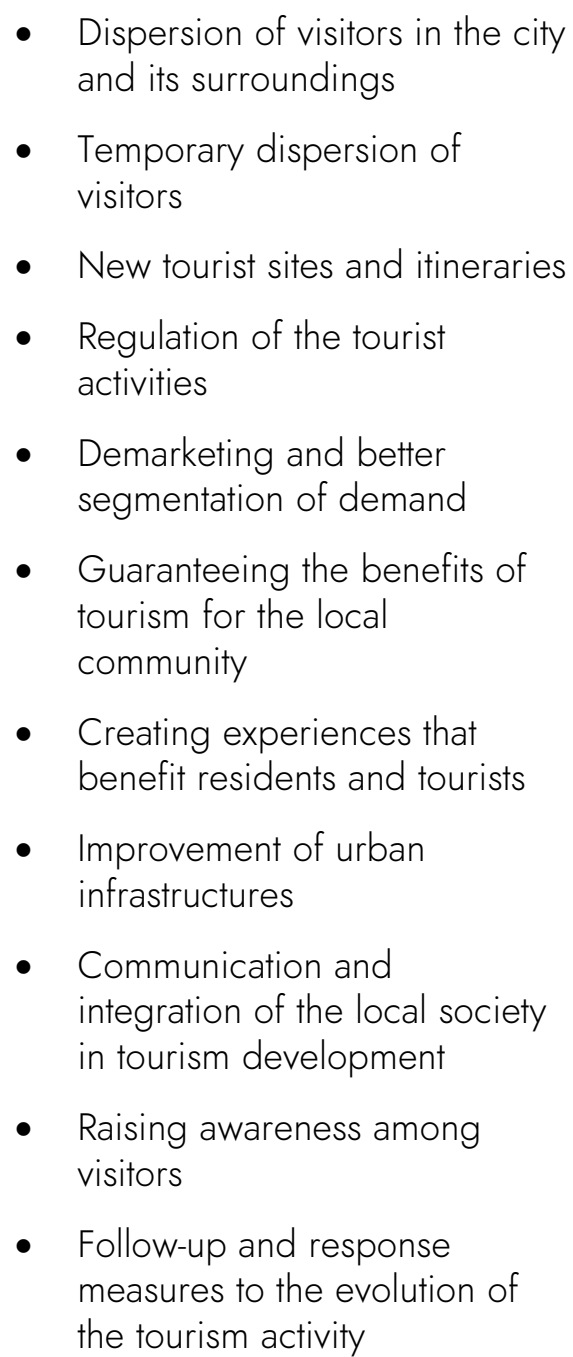 \\
\hline
\end{tabular}

Source: own elaboration based on Milano (2018), Peeters et al. (2018) and UNWTO (2018) difficult to resolve and that is why establishing mechanisms to prevent it should be a priority.

\section{Smart cities and destinations in response to overtourism: nature and scope of a new management approach}

Smart cities emerge as a new paradigm of planning and management based on knowledge, technology and innovation to respond to the exponential growth of the urban population (Komninos, 2015). Therefore, the approach is specifically directed at facing the challenges of urban management (Gretzel, 2018). For this reason, the extent to which smart cities are able to 
address the problems of overtourism should be considered. With this objective, the concept of the smart city and destination is synthetically analysed.

The pioneer study of Giffinger et al. (2007) structures the concept of the smart city into six spheres which, in general, are maintained in subsequent academic studies (Komninos, 2015) and technical reports (Accenture, 2011; IBM, 2010): smart economy, people, mobility, environment, quality of life and governance. The smart city is defined as "a fair and equitable city focused on its citizens that is continually improving its sustainability and resilience, making the most of the available knowledge and resources (particularly ICTs) in order to improve the quality of life, the efficiency of urban services, innovation and competitiveness without compromising future needs in terms of economic, governance, social and environmental aspects" (Norma UNE 178201:2016).

The holistic concept of the smart city, therefore, integrates elements related to overtourism which are summed up in urban indicators such as the quality of housing, social cohesion, educational and cultural infrastructures, sustainable management of natural resources or safe and sustainable public transport. This approach is reinforced through the standard ISO 37120 (Sustainable development in cities. Indicators for urban services and quality of life), which serves as a reference for smart cities in the international context (Merricks, 2019). However, a more detailed analysis of the proposed indicators reveals that the tourism activity and its effects on the city are practically not addressed. For example, there are no specific tourism indicators and the most closely related, namely recreation, measures the squared metres of public recreational space per capita (ISO 37120).

Despite its comprehensive nature, the smart city approach lacks a real vision of the impact of tourism on the city. On the other hand, the rapid digitalisation of the tourism sector has shaped a smart ecosystem which Gretzel et al. (2015) define as a system that makes use of smart technology to create and manage services and/or experiences through an intensive use of information. The adaptation to this ecosystem implies the development of smart tourist destinations as a way to maintain and increase competitiveness but also to improve the quality of life of the residents and the satisfaction with the tourism experience (Boes et al., 2015; Buhalis and Amaranggana, 2013).

In order to guide the evolution towards smart destinations, AENOR (the National Standardisation Agency), in collaboration with SEGITTUR, has adopted two regulations relating to SD: UNE 178501:2016 (Management Systems of Smart Tourist Destinations. Requirements), revised in 
2018, and UNE 178502:2018 (Indicators and Tools of Smart Tourist Destinations). A commitment to the standardisation of processes in Spain which has been met with a positive response from international organisations (OECD, 2018).

On the other hand, the theoretical conceptualisation of smart destinations influences how new technologies and data sources are applied to management but also implies a greater emphasis on governance and the strategic management of the destinations (Gretzel, 2018). In this sense, the model proposed by Ivars-Baidal, et al. (2017) has a systemic nature which is structured on three levels: the strategic-relational level, based on governance with sustainability, innovation and public-private cooperation as fundamental pillars; the instrumental level, configured by digital connectivity and information systems; and the applied level, which provides the solutions for the management of the destinations in areas such as tourist information, the improvement of the experience, the management of resources and visitors and competitive intelligence. Ideally, the strategic-relational level defines the urban-tourism model and the priorities of action and therefore guides the application of the technological solutions in the destination in accordance with its needs.

On a theoretical level, the smart cities and destinations approach seems suitable for managing the tourist saturation processes provided that the comprehensive vision of the city incorporates a better knowledge of the tourism activity and the smart destinations strategy reconciles the improvement in competitiveness with the quality of life of the residents. Consequently, the processes associated with the management of smart cities and destinations should converge, particularly when they address complex problems such as overtourism.

However, the initiatives developed in practice in the context of smart cities raise many questions which are reflected in highly critical appraisals. Its technocentrism is questioned, as it favours the privatisation of public services and the interests of private corporations, generating a greater dependency on technology while promoting the depoliticising of the management of the city and compromises the privacy of its citizens (Greenfield, 2013; Hollands, 2008; March and RiberaFumaz, 2016; Townsend, 2013; Vanolo, 2014). The view of the smart city as a set of technologies which their promoters presume, in a deterministic way, to have positive effects (Cowley, et al., 2018), without considering the local context and with an instrumentation of a political nature is evidently problematic (Kitchin, 2015). Cardullo and Kitchin (2018) developed this interpretative framework that associates the smart cities with neoliberal ideals and their dogmas (efficiency, sustainability and freedom of choice) to call for a model of smart city that 
places the citizens at the centre, conventionally occupied by capital and the market. These authors refer to the example of the necessary reform of the smart city model of Barcelona initiated by the progressive government in 2015. As a result, it has promoted a greater technological sovereignty, it has combined the digital revolution with a democratic revolution and has repoliticised the smart city. However, these achievements have not prevented the city of Barcelona from suffering from significant overtourism processes which the smart city strategy has still not been able to mitigate.

Undoubtedly, the smart city focused on its citizens is the most suitable for managing overtourism. The neoliberal view implies the assumption, pointed out by Hall (2019) for sustainable tourism, that a greater efficiency within the status quo of continued tourism growth is necessary. However, the problems associated to overtourism may require more radical measures that limit growth, and even promote the degrowth of tourism (Blanco et al., 2018; Milano et al., 2018).

\section{Smart solutions applied to overtourism}

Tourist destinations experiencing overcrowding processes need to apply measures that improve the management of tourist flows, minimising undesired negative impacts. In view of this reality, over the last two years, institutional documents have been elaborated on a national and international level with crossed references between overtourism and technological solutions, all with generally optimistic approaches with respect to the role of ICTs as allies to control or diminish the effects of overtourism in urban destinations. In the next section, a synthesis of the technological solutions used on an international scale is made to then identify the technological solutions contemplated in the subsidised smart city and/or destination projects in Spain.

\subsection{Overcrowding and smart solutions on an international level: in search of compared references}

Although the technological solutions applied to the management of overtourism are not always framed within smart city and/or destination projects, their use has clear similarities with this management approach. Based on the bibliographical and documentary analysis ${ }^{1}$, Table 2 summarises the different technologies applied to the measures that seek to reduce and mitigate overtourism in urban spaces, including examples of different European cities. The measures that

1 Reports and publications by public bodies and different organisations (World Tourism Organisation, European Parliament, World Travel and Tourism Council, SEGITTUR, ...). 
link tourist frequentation with the local society have been grouped into one section because it has been established that there is a very low degree of application of technological solutions.

\section{Table 2. Summary of technological solutions applied \\ to overtourism in an international context}

\begin{tabular}{|c|c|c|}
\hline Measure & Technology applied & Example of application \\
\hline $\begin{array}{l}\text { Dispersion of } \\
\text { visitors in the } \\
\text { city and its } \\
\text { surroundings }\end{array}$ & $\begin{array}{l}\text { - Sensoring (using cameras or } \\
\text { other devices) to inform about } \\
\text { the congestion of spaces and } \\
\text { facilitate information to } \\
\text { suggest alternative visits } \\
\text { - Virtual reality videos } \\
\text { - Mobile applications with new } \\
\text { experiences in the destination }\end{array}$ & $\begin{array}{l}\text { - System for predicting the volume of visitors to a } \\
\text { tourist site in the city within the Respect the City } \\
\text { programme of the Dubrovnik City Council. } \\
\text { Tourists can consult the expected volume of visitors } \\
\text { in defined time slots on the destination's website } \\
\text { - Use of } 360^{\circ} \text { virtual reality videos on the I } \\
\text { Amsterdam website, showing all of the attractions } \\
\text { of the city and its metropolitan region } \\
\text { - An initiative that forms part of the joint promotion } \\
\text { of the metropolitan area of Amsterdam, awarded } \\
\text { by the UNWTO for the campaign "Visit } \\
\text { Amsterdam, See Holland" } \\
\text { - Mobile application: Play London with Mr. Bean } \\
\text { (Pointvoucher Ltd; Visit London, etc.) }\end{array}$ \\
\hline $\begin{array}{l}\text { Temporary } \\
\text { dispersion of } \\
\text { visitors }\end{array}$ & $\begin{array}{l}\text { - Tourist cards of the } \\
\text { destination } \\
\text { - Social network marketing }\end{array}$ & $\begin{array}{l}\text { - The use of the cards in different cities avoids } \\
\text { queues at the most visited attractions and enables } \\
\text { attractions different to the conventional sites to be } \\
\text { enjoyed (this is the case of the tourist card of the } \\
\text { city of Florence). } \\
\text { - Influencer campaigns (Switzerland Tourism) }\end{array}$ \\
\hline $\begin{array}{l}\text { New tourist sites } \\
\text { and itineraries }\end{array}$ & $\begin{array}{l}\text { - Digital contents on the official } \\
\text { website of the destination and } \\
\text { social networks } \\
\text { - Mobile applications with } \\
\text { alternative attractions }\end{array}$ & $\begin{array}{l}\text { - Campaign: Detourism: Travel Venice Like a Local } \\
\text { (City Council of Venice, 2014): Informs visitors of } \\
\text { different tourist attractions other than the iconic } \\
\text { sites and of the need for a behaviour that is more } \\
\text { aware and responsible } \\
\text { - Stockholm, Vilnius (Lithuania), etc. } \\
\text { - In Prague, the tourist card is marketed as a mobile } \\
\text { application and campaigns are developed such as } \\
\text { "Prague is yours, too", to promote alternative tours } \\
\text { on foot (Prague Tourism 2018). }\end{array}$ \\
\hline $\begin{array}{l}\text { Regulation of the } \\
\text { tourist activities }\end{array}$ & - Georeferenced databases & $\begin{array}{l}\text { - Used in different cities to locate and quantify tourist } \\
\text { accommodation supply } \\
\text { - Another application is the monitoring of traditional } \\
\text { activities to prevent their disappearance (protection } \\
\text { of the "Shops with History" in Lisbon). }\end{array}$ \\
\hline $\begin{array}{l}\text { Demarketing } \\
\text { (better } \\
\text { segmentation } \\
\text { and awareness } \\
\text { of demand) }\end{array}$ & $\begin{array}{l}\text { - Communication through } \\
\text { digital platforms and social } \\
\text { networks }\end{array}$ & $\begin{array}{l}\text { - Campaign: Enjoy \& Respect (Amsterdam, 2018). } \\
\text { Aimed at young Dutch and British groups aged } \\
\text { between } 18 \text { and } 34 \text { with messages about what } \\
\text { cannot be done in the city and the consequences } \\
\text { (fines). Using georeferencing techniques, } \\
\text { messages are sent to this segment when they } \\
\text { access the most congested places of the city }\end{array}$ \\
\hline
\end{tabular}




\begin{tabular}{|c|c|c|}
\hline $\begin{array}{l}\text { Creation of } \\
\text { experiences that } \\
\text { benefit residents } \\
\text { and tourists. } \\
\text { Communication } \\
\text { and integration } \\
\text { of the local } \\
\text { society in } \\
\text { tourism } \\
\text { development }\end{array}$ & $\begin{array}{l}\text { - Mobile applications, } \\
\text { websites and social } \\
\text { networks }\end{array}$ & $\begin{array}{l}\text { - The application "My Helsinki" promotes the } \\
\text { possibility of interacting with local people and } \\
\text { encouraging tourists to behave responsibly and } \\
\text { the local companies to guarantee sustainability and } \\
\text { mitigate the effects of the tourism activity on } \\
\text { climate change. } \\
\text { - Vilnius (Lithuania) combines the use of mobile } \\
\text { applications with a programme of volunteering } \\
\text { and integrating the local agents to offer new } \\
\text { tourist experiences }\end{array}$ \\
\hline $\begin{array}{l}\text { Improved use of } \\
\text { urban } \\
\text { infrastructures }\end{array}$ & $\begin{array}{l}\text { - Sensoring for environmental } \\
\text { monitoring (e.g. air and } \\
\text { acoustic pollution). } \\
\text { - Optimisation of the use of } \\
\text { the public transport network } \\
\text { through information in real } \\
\text { time to users within the } \\
\text { framework of the } \\
\text { Sustainable Urban Mobility } \\
\text { Plans } \\
\text { - Energy efficiency and } \\
\text { management of the water } \\
\text { cycle }\end{array}$ & $\begin{array}{l}\text { - Technologies applied to the management of the } \\
\text { urban transport system in Barcelona or Rome (bus } \\
\text { tourist routes, stops and car parks) } \\
\text { - Information about traffic conditions in real time for } \\
\text { residents and tourists (Valencia or Salzburg) } \\
\text { - Veovo BlipTrack Guest Predictability, through the } \\
\text { use of sensors and Big Data to manage the flows } \\
\text { of users (Airport of Amsterdam, among others) } \\
\text { - Smart parking (vacancies in public car parks in } \\
\text { Valencia available in a QuickDashboard for } \\
\text { residents and tourists) } \\
\text { - Signs (traffic lights connected to sensors) to guide } \\
\text { the visit in public spaces where there is a risk of } \\
\text { overcrowding (Florence or Madrid) } \\
\text { - Smart building (Use of technologies for the } \\
\text { management of public buildings such as } \\
\text { museums, conference centres, etc.) (Ruzafa } \\
\text { market real time info in Valencia) } \\
\text { - Management of historical heritage (Smart Heritage } \\
\text { City Project in Ávila) } \\
\text { - Smart Grid technologies for energy efficiency in } \\
\text { Málaga } \\
\text { - Water management system using Artificial } \\
\text { intelligence (Benidorm) } \\
\text { - Bicycle-friendly transportation system } \\
\text { (Copenhagen) }\end{array}$ \\
\hline
\end{tabular}




\begin{tabular}{|c|c|c|}
\hline $\begin{array}{l}\text { Follow-up and } \\
\text { response to the } \\
\text { evolution of the } \\
\text { tourism activity }\end{array}$ & $\begin{array}{l}\text { - Monitoring tourist flows } \\
\text { through the localisation of } \\
\text { mobile devices, Wi-Fi } \\
\text { networks, the use of tourist } \\
\text { cards of the destination, } \\
\text { monitoring of information in } \\
\text { social networks, distribution of } \\
\text { payments made with credit } \\
\text { cards, etc. } \\
\text { - Sensoring of urban spaces and } \\
\text { events with a large influx of } \\
\text { people } \\
\text { - Information and tourist } \\
\text { intelligence systems (big data) }\end{array}$ & $\begin{array}{l}\text { - Amsterdam: system of monitoring the } \\
\text { massification of public spaces based on Wi-Fi } \\
\text { sensors and smart cameras. Initially applied to } \\
\text { the Red Light District and the main shopping } \\
\text { street of the city. There are plans to extend it to } \\
\text { the whole of the city. It involves the coordination } \\
\text { of the Department of Traffic and Public Space } \\
\text { with the police, always guaranteeing the privacy } \\
\text { of the passersby. } \\
\text { - Amsterdam City Card and other tourist cards in } \\
\text { different European cities } \\
\text { - Tourism of Portugal, in collaboration with the } \\
\text { telecommunications company NOS, has } \\
\text { developed a pilot project with the use of mobile } \\
\text { data, accommodation information in Airbnb and } \\
\text { social network data to measure the pressure of } \\
\text { tourism on Lisbon and Oporto. }\end{array}$ \\
\hline
\end{tabular}

Source: own elaboration based on Dichter and Gloria (2017), Dodds and Butler (2019), European Cities Marketing (2018), Exceltur (2019), Peeters et al. (2018), Turisme Comunitat Valenciana and CERCLE (2019) and UNWTO (2018)

Generally speaking, the systemisation of the information available on the application of measures in European cities reveals a very low level of maturity and generalisation of the technologies identified, a circumstance attested by the high number of pilot projects. However, their instrumental value is undeniable for supporting measures that prevent or reduce overtourism through the generation of useful information for management and the interaction with tourists and the local society (Eckert et al. 2019; Turisme Comunitat Valenciana and CERCLE, 2019). In any event, the smart solutions cannot be developed in an isolated way and their capacity to revert overtourism processes still seems very limited.

\subsection{Technological solutions derived from the aid for the development of smart cities and destinations in Spain}

The public calls for projects on a state level within the framework of executing the plans for the Digital Agenda in Spain have promoted the implementation of technological solutions adapted to different needs of urban and territorial management. In the two calls for projects of the National Plan of Smart Cities, 25 initiatives were financed ${ }^{2}$. In the National Plan of Smart Territories in the

2 Developed among others in some cities with a tourist dimension such as Granada, Sevilla, Toledo, Huelva, Cáceres, Segovia, Valencia, Valladolid, A Coruña, Madrid, Santiago de Compostela, Zaragoza, Palencia, Gijón, 
category Smart Tourist Destinations 26 proposals have also been selected. The "Smart Tourist Destinations" that already implement the methodology of SEGITTUR for the integrated planning of tourism in the destinations include cities such as Almería, Badajoz, Benidorm, Donostia-San Sebastián, Las Palmas de Gran Canaria, León, Murcia or Palma ${ }^{3}$.

A considerable volume of investment (180 million euros in the rounds of calls for projects of the "Smart cities and islands" and 73.97 in the SD call for projects of "Smart Territories") has been made in different projects. Table 3 classifies the technologies used in the funded projects, distinguishing between technologies applied to urban and tourism management, in the latter case related to tourist information, marketing and business intelligence.

Table 3. Technologies applied in projects funded by public programmes in Spain

\begin{tabular}{|l|l|}
\hline \multicolumn{1}{|c|}{ Urban management } & Tourism management and marketing \\
\hline - Sensoring & - Websites \\
- Spatial Data Infrastructure & - Mobile applications \\
- Big danagement platforms & - Customer Relationship Management \\
- Open data & - Beacons \\
- Traffic management systems & - 3 D technologies applied to tourist \\
- Management of water metres & - Tttractions \\
- Smart parking systems & - Tourist cards \\
- Street lighting control system & - Open wifi network \\
- Citizen participation platform & - Seach monitoring systems \\
- Data processing centre & - Intelligent analytical systems for tourism \\
- Interactive totems & data (including Big and Open Data) \\
\hline
\end{tabular}

Source: own elaboration based on the analysis of publicly financed projects

The application of these technologies is not connected to overtourism in the description of the projects. Nevertheless the experiences in the cities with a greater tourist pressure and the opinion of the managers interviewed for this study highlight the potential for a more efficient management of tourism.

Las Palmas de Gran Canaria, Santander, Murcia, Alicante, Ponferrada or Lugo (https://www.red.es/redes/es/que-hacemos/ciudades-inteligentes) 


\section{Donostia-San Sebastián, Madrid, Málaga, and Valencia as case studies: overtourism, tourism planning and smart city and smart destination policies}

\subsection{Growth of visitor flows and (the perception of) overtourism}

The cities of Donostia-San Sebastián, Madrid, Málaga and Valencia are long-standing tourist destinations and today they attract large and growing volumes of visitors. Despite the degree of vagueness in their quantification, the data from the available statistical sources show spectacular growth of certain parameters that are comparable from a time perspective on a country scale, such as the places offered in registered accommodation establishments and the travellers staying in them. Between 2014 and 2018, the number of travellers staying in hotels, for example, grew in the four cities. Málaga has experienced a relatively higher growth $(+34 \%)$ but in Madrid $(+16 \%)$ in absolute terms the increase is more than significant, 1,3 million more travellers with respect to 2014 (INE, 2019). The quantitative importance of the supply of housing rented to tourists marketed on digital platforms can be observed. Furthermore, in the case of the coastal cities, the growth in the number of cruise passengers is also noteworthy.

This strong expansion of the tourism activity has given rise to debates in different forums. The civil society (organised through several citizen platforms) channels different movements responding to the growth of tourism in the four cities considered (Milano, 2018). The academic sphere is also making efforts to identify, measure and evaluate the negative impacts of tourism, their embodiment in the city on a socio-functional level. It is also reflecting on the different aspects of the phenomenon (touristification, gentrification, tourismphobia...). In Donostia-San Sebastián there is particular concern about the impacts of tourism on the old quarter called Parte Vieja (Camio Olaskoaga, 2016; García-Hernández et al., 2017). In the case of Madrid, studies have been carried out on the expansion of the tourism footprint (Calle Vaquero et al., 2018) and also on the growth of properties used for tourism, their relationship with gentrification and touristification processes and the social movements that reject tourism (Gil \& Sequera, 2018). Muñoz Gónzalez (2016), Marín Cots (2017), Navarro et al. (2018) and Almeida García (2018) investigate about these elements with respect to the city of Málaga and in the case of Valencia, Torres Mora (2018) analyses the anti-tourism movements in the Barri del Carme.

From the local tourism management point of view, the perceptions of the phenomenon are different. The tourism experts and managers interviewed do not detect serious overtourism problems. In Donostia-San Sebastián, they are aware of the inconveniences caused by the mass 
influx at certain moments in the year (saturation of the beach, of car parks and the public space of the Old Quarter), they express concern about the impacts derived from the growth of housing rented to tourist and they acknowledge a problem of "human pressure" in the central spaces of the city. Those responsible for tourism in Madrid, Málaga and Valencia, however, consider that there are no overtourism problems in their respective cities. In Madrid, there is a perception of social change processes (gentrification) in certain popular neighbourhoods in the historical centre and it has been necessary to regulate the activity of housing used for tourism purposes from an economic perspective (unfair competition that has to be audited). On occasions, Málaga receives many visitors but it considers that the city "absorbs them well". However, there is a feeling of "frustration" due to the lack of capacity of the local councils with regard to matters relating to the regulation, control and decision-making about housing rented to tourists and cruises, the two critical aspects related to the growth of the influx of visitors to this city.

Finally, those responsible for tourism in Valencia affirm that there is an increasing number of tourists but there is no overcrowding. Special emphasis is placed on the increase in tourist apartments in the centre, the increase of rental prices and the "expulsion of young people" towards the suburbs, aspects which have been associated to tourism by the until now, weak antitourism movements. However, it is believed that some of the problematic aspects of tourism growth can be controlled. If it is possible to generate information about acoustic pollution, occupation of the public space, consumption of water to establish the occupancy of housing, etc., it would also be necessary to impose sanctions for the non-compliance with the regulations in these aspects. The double interpretation of the impacts of tourism in this city is interesting: the managers of the smart city and tourism strategies of the city interviewed believe that tourism entrepreneurs do not see problems but the population is beginning to perceive them. There is also an awareness of the overcrowding problems that will arise if the current growth rates of the tourism activity in certain streets of the historical quarter are maintained.

\subsection{Overtourism and smart solutions in tourism planning on a local scale}

The references to problems related to overtourism, the increase in visitor flows or the negative impacts of tourism on the city have a weak presence in the tourism planning documents in force in the cases analysed. Only the Plan de Turismo Donostia/San Sebastián 2017-2021 VISIT-BIZI expresses some concern about the increase in tourism. Among other actions it proposes several corrective measures, such as: a) the creation of a by-law governing the rental of properties to tourists to regulate tourist accommodation in the city centre; b) the implementation of campaigns 
to promote tourism in the low season and the enhancement of new tourism areas; c) the creation of an observatory which, with real time data, analyses the limits and carrying capacity of Donostia and the effects of tourism; e) the regulation of coaches with groups; $f$ ) improvement of real time information systems regarding mobility and parking in the city; or g) the elaboration of a Comprehensive Plan for the Old Quarter which implies the declaration of the saturated area (with restrictions to the implementation of certain tourist activities).

In Madrid, the Plan Estratégico de Turismo Madrid Destino 2015-2019 is distinctly oriented towards promoting the destination and the need to capture visitors, with no mention of the need to regulate flows and the implementation of tourism activities in the city. However, the city has sectoral regulations governing certain aspects related to overtourism, such as the Sustainable Mobility Ordinance (limiting and controlling the use of electric scooters, electric bikes and segways) and the "Special Plan for regulating the tertiary use in its accommodation category" and it has implemented a programme called Madrid 21 Distritos that seeks to promote all of the districts of the city among tourists in order to alleviate the overuse (tourist, leisure, commercial) of the central districts.

Meanwhile, the Plan Estratégico de Málaga 2016-2020 establishes a series of objectives related to the problems of tourism growth. It refers to the need to extend the tourism footprint, investigate the perception of tourism among the resident population or raise citizen awareness about the benefits of tourism for the destination (Awareness-raising Plan). In any event, the application of ICTs is focused only on the development of digital marketing. Finally, the Plan València turística, hacia 2020 is, perhaps the document which places most emphasis on smart solutions for tourism management in relation to four strategies: to create value for the visitor, to update the Valencia brand (a more segmented and technological promotion), to create a smart and sustainable destination and a transparent, efficient and collaborative governance. Although it does not use smart management tools, the Plan also includes measures for the management of some aspects related to the possible tourism overload such as the regulation of tourist accommodation or the implementation of awareness-raising campaigns.

\subsection{Smart City and Smart Destination Policies}

The four destinations analysed have initiated smart city strategies and projects, although with an unequal level of development and integration in the overall urban strategy and connection with the action plans for the municipal tourism area. Donostia-San Sebastián, Valencia and Málaga have generated some type of document to guide the smart city strategy. The four cities have 
already developed projects in this field and San Sebastián and Málaga also form part of SEGITTUR's SD programme.

Table 4. Case studies. Smart City and smart destination policies and strategies.

\begin{tabular}{|c|c|c|c|}
\hline \multirow[b]{2}{*}{ City } & \multicolumn{2}{|c|}{ SMART CITY } & \multirow[b]{2}{*}{ SMART DESTINATION } \\
\hline & $\begin{array}{c}\text { Strategic Smart City } \\
\text { plans }\end{array}$ & $\begin{array}{l}\text { Smart City } \\
\text { Projects }\end{array}$ & \\
\hline $\begin{array}{l}\text { Donostia-San } \\
\text { Sebastián }\end{array}$ & $\begin{array}{l}\text { Plan Smart Donostia-San } \\
\text { Sebastián 2016-2020 }\end{array}$ & $\begin{array}{l}\text { Light House (currently being } \\
\text { executed), Replicate ( } 20 \ldots- \\
\text { 20...), Smart Kalea, Opteemal, } \\
\text { Hotmaps, TechTown, Clean, } \\
\text { iSare }\end{array}$ & $\begin{array}{l}\text { In the SEGITTUR's SD programme } \\
\text { (since 2018). } \\
\text { Member of the SD Network } \\
\text { (Ministry of Tourism). } \\
\text { STD Diagnosis and Action Plan } \\
\text { Donostia-San Sebastián (2018) }\end{array}$ \\
\hline Madrid & & $\begin{array}{l}\text { MINT: Madrid Inteligente, Open } \\
\text { Data Portal, CIVIS: the social } \\
\text { history of the citizens, Platform } \\
\text { of activities, Génesis: } \\
\text { appointment management }\end{array}$ & \\
\hline Málaga & $\begin{array}{ll}\text { Strategic } & \text { Technological } \\
\text { Innvation } & \text { Plan 2018- } \\
2022 & \end{array}$ & $\begin{array}{l}\text { Smartcity Málaga (2009-2013), } \\
\text { Flexiciency (2015-2019), } \\
\text { ZeM2All (2012-2015), Green } \\
\text { Emotion (2012-2015), Open } \\
\text { Data Portal, City Apps, } \\
\text { employment, beaches, Easter, } \\
\text { car parks), } 0 .\end{array}$ & $\begin{array}{l}\text { Member of the SD Network } \\
\text { (Ministry of Tourism). } \\
\text { In the SEGITTUR's SD programme } \\
\text { (since 2018). }\end{array}$ \\
\hline Valencia & $\begin{array}{ll}\text { Valencia Smart } & \text { City } \\
\text { Strategic Plan } 2013 & \end{array}$ & $\begin{array}{l}\text { Smart City Platform (2014), } \\
\text { App Valencia, Impulso Vlci } \\
\text { (2016), ConectaVlci, } \\
\text { Valencialminut, Geoportal and } \\
\text { open data portal. }\end{array}$ & \\
\hline
\end{tabular}

Source: own elaboration based on the information

from institutional websites and interviews with managers

In San Sebastián, the smart city related aspects are developed by the public company Fomento de San Sebastián which elaborated the Plan Smart Donostia-San Sebastián 2016-2020. Like other cities it requests external finance (basically European) to develop projects linked to the priority issues in this field to which the city has given its attention: energy (and energy efficiency), the environment, mobility and ICTs. In parallel, and unrelated to this overall strategy, Turismo de San Sebastian is leading the participation in the SEGITTUR's SD programme. Beyond the technological bias of the smart approach in tourism, managers of tourism consider that the methodology of SEGITTUR's study is "highly important" given its transversality. In their opinion, working with the SD approach is highly relevant because it requires "coordination with many 
administrative sections and departments of the city council". In general, they believe that an SD is a destination that correctly implements all of the aspects of the methodology (Innovation, Technology, Governance, Sustainability, Accessibility) and this work approach broadens the preceding highly sectoral logic focused on marketing and attracting visitors, competitiveness and improving the quality of the tourism sector. In their opinion it enriches the perception of the city and also includes the suggestions of the Plan Director de Turismo (2017). It is deemed necessary to "manage a tourist city, not only the tourism in the city" on a municipal level.

Madrid does not have a guiding document for the smart city policy/strategy. However, it has developed several technological policies in order to promote the digital transformation of the urban administration. Some of these initiatives are coordinated by the Dirección General de Innovación y Promoción de la Ciudad (Subdirección General de Innovación y Smart City). However, the size of the city means that many departments are involved in the implementation of technological measures to improve the provision of services. The municipal managers highlight four projects: MINT: Madrid Inteligente, el Portal de Datos Abiertos, Plan A de Calidad del Aire y Cambio Climático y CIVIS: la historia social de la ciudadanía. Similarly, the introduction of the smart dimension in tourism management is carried out through projects. Madrid does not form part of the smart tourist destination programme of SEGITTUR, although on a technical level the possibility of beginning the process of certification as an SD is being considered. The tourism managers of the municipal company consider that implementing an SD strategy is administratively highly complex because it requires mobilising many resources, determining the assignment of responsibilities and working in a coordinated way with many departments. They understand that the law only attributes tourism promotion/communication responsibilities to the municipal government and the interpretation of the SD applications are made on this level.

Málaga is an active city in terms of smart city policies. The majority of the initiatives are coordinated by the Área de Nuevas Tecnologías del Ayuntamiento. In May 2018, the Plan Estratégico de Innovación Tecnológica 2018-2022 of the city was presented. In its third section it includes a "Digital Tourism" programme, referring to eight actions: Málaga Pass, Large Cities Plan, Environmental Spaces, Influx Control, Tourism Big Data, Web Portal, App and Flagship Office. Also in the Integrated Sustainable Urban Development Strategy EDUSI "PerchelLagunillas", operational until 2022 whose scope of action covers a good part of the urban centre, in the O.T.2 Objective there is a mention of a line of action regarding "Smart Cities". Furthermore, technological projects have been developed (many linked to European calls for projects) related to energy efficiency, mobility and traffic management, control of acoustic 
pollution, etc.: Smartcity Málaga (2009-2013), Flexiciency (2015-2019), ZeM2All (20122015), Green Emotion (2012-2015), etc. In relation to the SD strategies, in October 2018, Málaga signed the General Action Protocol for participating in, driving, supporting and promoting the Red de Destinos Turísticos Inteligentes de España (Smart Tourist Destination Network). The municipal managers of tourism consider that the city should incorporate the SD methodology and express great interest in positioning themselves at the forefront of tourism on the same level as the country's large urban destinations. Similarly, they consider this methodology to be interesting because it addresses the destination in a global way although they are somewhat concerned about how it links with other preceding work dynamics such as the tourism quality guarantee (there are 7 active certificates related to tourism in the city alone).

Meanwhile, Valencia is a municipality committed to the smart city strategy. It is one of the founding cities of the RECl and has a Smart City Office responsible for executing the Plan Estratégico Valencia Smart City 2013. Based on this document and also with regard to the aid from public calls for proposals, many projects have been developed in the city: Plataforma Smart City (VLCi) App València, Impulso Vlci; ConectaVlci, Valencialminut or the Geoportal and an open data portal, among others. Although Valencia does not form part of the Red de Destinos Turísticos Inteligentes (Smart Tourist Destination Network), those responsible for managing tourism report to have been working on SD logic since the beginning of the Strategic Plan 2015-2016 and are currently working on the València turística, hacia 2020. It is not one of the city's priorities to elaborate an SD plan, but the smart culture impregnates a good part of their work approaches in the field of tourism and much emphasis is placed on the need to manage information differently. Big data analysis is a key factor for improving the management of tourism on a local scale in terms of marketing and flow management. For example, the marketing of a destination is now considered to be based on data, not only on intuition or creativity.

\subsection{Smart solutions and the opinion of the managers}

The interviews conducted with tourism managers reveal a more or less recurrent series of technological solutions applied to the destinations. Although the catalogue visualised by the drivers of smart city and SD policies is broad, the level of real development still seems limited. In the destinations studied, it is possible to find the following elements of technological work: digitalisation of the tourist information office, website, destination apps, chatbots, beacons, incipient destination intelligence systems (from the traditional tourism observatories to the 
integration of sensorised data on platforms) and there is a commitment to digital marketing with special emphasis on social networks.

Donostia-San Sebastián is working on the implementation of a digital environment for the tourist information office ( $\mathrm{TIO}$ ) (tactile screen, printing of tourist maps, ...). It does not have a destination app because it believes that the levels of use by tourists are very low, but it is going to great lengths to maintain the website as the principal channel through which the tourist gathers information prior to travelling (responsiveness, translations, creation of differentiated content in terms of language/channel). It is considered to be highly active on social networks (Facebook, Twitter, Pinterest, Instagram) and is beginning to work with chatbots (outside the TIOs when they are closed). It is preparing a pedestrian signalling project which will incorporate beacons and a ticketing tool that enables the city to be to marketed through the website with the guaranteed purchase of services offered by non-associated companies via commission (Shop Donostia). Finally, it is developing a Programa de Buenas Prácticas en el uso de las TIC (Programme of Good Practice in the use of ICTs), working with companies in the sector on the implementation of ICTs in the businesses of the associates (with diagnoses of digital maturity and personalised improvement plans). Despite all of this technological development, the tourism managers of the city do not want to "fill the city with gadgets" and are happy that the technological issue does not have as much weight in the SD methodology of SEGITTUR as they had thought before incorporating into the programme. They consider that there is always a certain amount of political pressure to implement technological developments, particularly their "most spectacular" aspects.

The developers of Madrid Destino consider themselves to be pioneers on a technological level. They apply technological developments in the four strategic pillars of the organisation's Action Plan: improving tourist information services, sustainability, accessibility and exterior promotional campaigns. They are particularly active in actions related to the digitalisation of the tourist information office. In 2015, they implemented the SAGAT (Advanced Management System of the Tourism Activity) which seeks to optimise: a) the information service provided to the visitor ${ }^{4}$; b) the management of stock of information material (printed leaflets, maps...) and c) The processing of data generated by system consultations. It is also implementing the digitalisation system of biddings (internal level of management, electronic administration) and finally, and in

4 The informer, who is assisting the visitor in person, fills out an on-line questionnaire which associates the information requested and the consultations, packages the information in a pdf document and sends it by email to the mobile device of the tourist. The tourists themselves can also personalise the information through the use of tactile screens and send it to themselves. 
relation to the city-breaks segment (with the objective of stimulating demand in the low season) they are developing a tool that will work through Facebook. It is a programme in which the visitor, when subscribed and consuming several tourism-cultural services in the city (musicals, cinema...) accumulates points for discounts in the associated establishments. Together with these work bases, the website and social networks also channel the on-line marketing efforts of the organisation.

Although it does not have an SD strategy yet, Málaga is developing a series of technological solutions within the framework of different city council programmes. For example, there is a project in progress for the digitalisation of the TIO financed by the EDUSI EI Perchel-Lagunillas. Furthermore, in November 2018, Málaga received the smart tourism award in the category of accessibility in the competition European Capital of Smart Tourism 2019 of the European Commission. Among other aspects, it acknowledged the fact that Málaga has an inventory of accessible points of the city, a tourist information chatbot ("Victoria la Malagueña"), a correct treatment of the public space and a high degree of accessibility in municipal buildings, beaches, urban transport, etc. The city is also developing a project to place beacons in signs which can be used as flow counters and there is also an Interreg European project underway called ALTER ECO which is based on the development of an application which, using telephone data, calculates the tourist flows in the streets of the historical quarter. Málaga also has two destination apps. In general terms, the tourism managers of this city consider the implementation of technologies as positive. However, they believe that the level of interaction of the tourist with them in the street is low. They place a lot of importance on the website and social networks and highlight its advantageous positioning as the second tourist destination in Spain in terms of number of followers.

The tourism and smart city managers in Valencia consider that the city has reached a significant level of technological maturity related to actions concerned with augmented reality, the virtual tourist office and the development of digital marketing in the whole of the travel cycle. They have implemented the Tourist card, interactive totems, the Valencia App (with tourist and citizen profiles) and free Wi-Fi in public spaces. The tourist card is in the process of being improved. Information will be received through it about what the tourist is doing (although collaboration from the private sector is still needed). The mobile destination app knows the location of the tourist at all times, but its level of use and download rate is very low and does not seem of great interest for the managers. In addition, a CRM (Customer Relationship Marketing) and System of Tourism Intelligence (SIT) are also being created. The CRM has the objective of improving the 
relationship with: tourists, local agents and issuing market agents (OTA, prescribers, journalists, etc.). The SIT, on the other hand, is being created to generate information for the associated entrepreneurs and is made up of two control panels: 1). Accommodation (occupancy, average price, tourists, overnight stays, RevPar, average stay, etc.), 2). Airline sector (supported by the Valencia-based company Forward Keys that buys the information from AMADEUS and OTAS and conducts big data analyses, for example, to differentiate demand profiles between different airports): tourist profile by airports, scheduled flights differentiated by routes and destinations (slots), future bookings etc. However, the great challenge for Valencia lies in the convergence between tourism management (Turismo Valencia) and the ICT Service of the City Council and in the use of common tools such as Geoportal, the city App, the open data portal and the development of the CRM of tourism.

Among all of these technological solutions there is hardly mention of applications related to the management of overtourism. In a very early phase of the projects the focus is still on the monitoring and capturing of data for decision-making and an alleged real time management of visitor flows. The ALTER ECO project of Málaga, for example, calculates the tourist flows in the historical quarter with the idea of designing four alternative routes in order to disperse the flows and de-congest the most saturated space. The flows have been measured before the routes are promoted and the flows will be measured again after the project has been implemented. Valencia also emphasises the use of big data and the need to monitor the use of the destination app and the bike lane/cycling loop (in the project phase). And Connecta Valencia (a project cofinanced by Red.es) will install a network of sensors that will capture the mobile devices to differentiate between tourists and residents and, in the future, it will be able to measure displacements in different cities of the province of Valencia.

\subsection{The System of Tourism Intelligence}

In the case of the four cities, the aspects related to the development of systems of tourism intelligence deserve special attention as the generation of data and their processing always appears as a key factor for tourism managers. In Donostia-San Sebastián there is interest in starting a project to design a system of this type (taking as a reference the project carried out in Valencia). They intend to work with massive data, being able to buy information and process the data that they generate themselves. They seek to generate knowledge, providing open data, data for partners and data for non-associated companies. Currently, they are working with two companies that generate data and undertake studies with a traditional observatory format. On an 
operational level, the tourism managers of San Sebastián advocate the definition of a protocol for processing tourist information that is standardised on a state level because it would improve the functioning of networking. In their opinion, there is still an important gap in the use that is made of the data: the step has still not been made from "data to gain learn" to "data to manage". However, on a municipal level, there are plans to create a city observatory, integrating all the data generated by the different municipal departments and working with its own technological development. However, the Public Works department of San Sebastián, which has developed the projects that involve the implementation of sensors in the city, acknowledges the existence of a serious data management problem. Each project has a technological development associated to it (which implies sensoring) and which is managed by a platform which can be worked with on different levels and different information maps: management on an IT managers level (data collection and processing), management on an urban managers level (data knowledge and processing for management and decision-making) and management on a citizens level (open data, open access and automatic generation of reports for diffusion). This proliferation of noninterconnected platforms is a problem today for the city council which is receiving large volumes of information which it cannot process usefully or comprehensively.

Madrid has created a "Tourism Intelligence Centre" for analysing data of interest for the sector. However, the municipal tourism company is a data user and only generates its own data relating to the TIO consultations and the use of the website. The importance of generating tourism intelligence is acknowledged as it allows the expansion of markets and the direction of communication campaigns towards strategic sectors of the city. They are currently working in line with an open tourist data policy, for example, they maintain a database of tourism resources open which is at the free disposal of the citizens and other administrative bodies. Meanwhile, the tourism service of Málaga affirm that they collect data (app downloads, use of QR codes), but they do not process this information. However, they maintain a tourism observatory that works in a traditional way, generating reports based on short-term data of the official organism and streetlevel surveys.

Valencia is perhaps the city with the most innovative initiatives in this sense. In 2014 it implemented a project for a data management platform (VLCi). It is a smart city platform that, in a single repository, gathers information from the systems of the city council and the sensors placed around the city. The data are subsequently analysed with big data tools. It is a project based on the following elements: interoperability, integration of municipal information (breaking administrative silos), transparency and monitoring of management indicators. The Open Data 
portal has a tourism section with a certain level of reuse. In fact, special emphasis is placed on the integration of tourism data in the control panel of the platform and the generation of knowledge through big data analysis. However, the managers acknowledge that having information is expensive and that, using it and exploiting it in real time requires many resources with workforces which must incorporate new types of professionals (IT specialists, data analysts...). Today, the development of sensoring and capturing data is not consistent with the low capacity for processing this information that the administration has in its possession.

\section{Conclusions}

There are many urban destinations that suffer or are prone to suffering from overtourism processes and the problems derived from them. The on-the-spot identification of the phenomenon, its measurement and assessment are controversial aspects that are subject to many value judgements and self-serving positioning. In parallel, international organisations identify overtourism with a deficient management of urban tourism and propose a broad catalogue of measures among which the positive role of technology in the form of smart solutions is prominent. This study associates this course of action with the approach emerging in the smart cities and destinations with the objective of analysing the current scope of these types of solutions.

However, before referring to the solutions it is important to mention the perception of the overtourism problem. Its practically marginal presence in the tourism plans analysed reflects its incidental nature and the need to address the management of the tourism city in a different way. It is a complex, multicausal problem that requires new management approaches that exceed the sectoral vision of tourism consistent with the studies that call for a transversal (López Palomeque, 2015) or holistic management (Eckert et al., 2019) that go beyond the predominant marketing approach (Dredge, 2016).

The comprehensive nature of the smart city seems like an appropriate approach provided that the collaboration with local tourism management is strengthened, which should make the improvement of the competitiveness of the destination compatible with the sustainability of tourism development in all its dimensions. The convergence of the city strategy with the smart destination is a key success factor according to the tourism managers, although it has been shown that the administrative coordination is improving very slowly. However, the overtourism problems have favoured the incorporation of tourism into the agenda of the smart cities and the 
measures to address them facilitate the development of projects shared between different municipal areas.

In view of the foreseeable intensification of the factors that trigger overtourism and the symptoms detected in the cities analysed, in a more or less localised way, it is necessary to make a more indepth strategic reflection of these dynamics in order to favour a preventive approach as opposed to the development of corrective measures, which is more common. The potentiality of the technological solutions and their supposed efficiency cannot constitute a pretext to avoid measures of a greater scope such as limiting the growth of supply and tourism demand, and even de-growth. Smart solutions are compatible with these types of policies and can become a fundamental support.

However, the measures identified based on the documentary analysis of international management experiences and co-financed public projects have a largely weak scope (demarketing, innovative websites, social network communication, mobile apps, tourism intelligence systems, etc.) and are incapable of reverting tourist overcrowding processes as noted in different studies (Koens et al., 2018; UNWTO, 2018). Furthermore, as the projects are often experimental and temporary, their integration in management processes is very slow, and requires the development of resources and capacities which local governments do not always have available.

This is why there is a need to avoid any technological bias and prioritise governance processes in accordance with the needs of each destination. The systemic model (Ivars et al., 2017) does not work in practice as temporary technological solutions based on specific projects are prioritised over an approach that integrates the strategic, instrumental and applied levels. This bias could be corrected as the smart strategies become more consolidated and the governance of the city is prioritised over technological solutions that are effective but of limited scope, as noted by the interviewees. On the other hand, the case studies reflect the gap between the institutional discourses and the measures adopted on a local scale, even in cities with a considerable urban range and a robust administrative structure such as those studied, a circumstance which reflects the difficulty in applying smart solutions in cities with a lower demographic weight.

In short, smart solutions are gradually improving urban and tourism management in the cities but their application is complex from an organisational point of view and in terms of the availability of economic and technical resources. In this context, it is difficult for these solutions to resolve the overtourism problem alone but it does not seem as though this problem will be overcome without 
recurring to the capacities of the new technologies for diagnosing the situation and applying the most appropriate measures.

Finally, this study refers to the limitations derived from the object of the research itself. On the one hand, despite their significant media impact, smart cities/destinations are still a reality under construction and on the other, the overtourism processes are a new in terms of their intensity and diversity depending on the cities analysed. This is why a qualitative study has been carried out that compares planning and management instruments with the experience of those responsible for tourism management, in order to measure the advances in the smart strategy and identify how to address overtourism management. The conclusions obtained could vary in other case studies. This highlights the relevance of each local context when analysing smart strategies and overtourism processes, demonstrated in the cities analysed. However, the results obtained substantiate the advantages of a better integration of overtourism in the agenda of smart cities/destinations, although they also warn about the risk of oversizing the problem of overtourism and overestimating the smart solutions if they do not form part of a true governance of the destination.

This is an open research field in which future studies will examine in greater depth, from different perspectives, the causes, nature and impact of excess tourism and its repercussion on the overall operability of the city and the efficiency of the actions to measure and prevent it.

Acknowledgments: This work was supported by the Spanish National R\&D\&I Plan financed by the Ministry of Economy and Competitiveness under Grants CSO2016-75470-R (research project: Transformations of the historical urban landscape caused by tourism: contradictions and controversies, government and governance) and CSO2017-82592-R (research project: Analysis of planning processes applied to smart cities and tourist destinations. Balance and proposal of a new methodolgy: Smart Tourism Planning).

Authorship statement: The authors declare no conflict of interest. They also declare that all of them jointly have carried out the tasks of the research approach, of the writing of some of the parts of the manuscript and of the final reflection. However, the main contribution of each author has been distributed as follows: Josep Ivars-Baidal has developed the theoretical framework and performed some of the interviews (field work), as well as the final revision of the manuscript. Sofía Mendoza de Miguel and María García-Hernández also conducted some interviews and the content analysis 
of the plans. María García-Hernández carried out the methodological approach, the final exploitation of the results of the fieldwork and the writing of the cases. 


\section{References}

Accenture (2011). Building and managing an intelligent city. Accenture Management Consulting. Retrieved from https://www.fm-house.com/wp-content/uploads/2015/01/Building-ManagingIntelligent-City.pdf

Almedia-García, F. (2018). Tourim phobia and Gentrification in Málaga (Spain). In Atlas Annual Conference 2018 Destinations Dynamics Abstract book (Pdf file). Retrieved from

http://www.atlas-

euro.org/LinkClick.aspx?fileticket=N6P3VbnsWhw\%3d\&tabid=280\&language =en-US

Ajuntament de València (2013). Plan Estratégico Valencia Smart City 2013. Retrieved from https://www.lasnaves.com/wp-content/uploads/2017/01/Pla-Estrat\%C3\%A8gicVal\%C3\%A8ncia-Smart-City-2013.pdf

Ayuntamiento de Madrid (2014). Plan Estratégico Madrid Destino Resumen Ejecutivo. Retrieved from

https://www. madrid-destino.com/sites/default/files/2018-

05/Plan\%20Estrat\%C3\%A9gico\%20Turismo\%202015-2019_Madrid\%20Destino.pdf

Ayuntamiento de Málaga (2016). Plan Estratégico del Turismo de Málaga 2016-2020. Retrieved from https://ciedes.es/images/stories/Laura/PLAN_2020/2PLAN_ESTRATEGICO_TurismoMal aga.pdf

Ayuntamiento de Málaga (2018). Plan Estratégico de Innovación Tecnológica 2018-2022. Retrieved from

http://malagasmart.malaga.eu/opencms/export/sites/msmart/.content/galerias/documentos/ Plan_Estrategico_de_Innovacion_bajares.pdf

Boes, K., Buhalis, D., \& Inversini, A. (2015). Conceptualising Smart Tourism Destination Dimensions. In Tussyadiah, I., and Inversini, A., (Eds.), ENTER 2015 Proceedings (pp. 391404). Lugano, Springer-Verlag, Wien. https://doi.org/10.1007/978-3-319-14343-9_29

Buhalis, D., \& Amaranggana, A. (2013). Smart Tourism Destinations. In Z. Xiang \& I. Tussyadiah (eds.), Information and Communication Technologies in Tourism 2014 (pp. 553-564). Cham: Springer International Publishing. Retrieved from http://link.springer.com/10.1007/978-3-319$\underline{03973-2440}$ 
Blanco-Romero, A., Blázquez-Salom, M., \& Cànoves, G. (2018). Barcelona, Housing Rent Bubble in a Tourist City. Social Responses and Local Policies. Sustainability, 10(6), 2043. https://doi.org/10.3390/su10062043

Calle Vaquero, M. de la, Ferreiro Calzada, E., \& Mendoza de Miguel, S. (2018). Concentración y desconcentración de la actividad turística sobre el espacio urbano. Reflexiones en torno a Madrid. Polígonos. Revista de Geografía, 30, 143-170.

Camio Olaskoaga, M. (2016). Análisis de los beneficios y costes socio-culturales del turismo en la Parte Vieja de Donostia-San Sebastián (País Vasco), desde la perspectiva de sus residentes (Master Thesis, Universidad de Barcelona, Spain) (Unpublished).

Cardullo, P., \& Kitchin, R. (2018). Smart urbanism and smart citizenship: The neoliberal logic of 'citizen-focused' smart cities in Europe. Environment and Planning C: Politics and Space, 118. https://doi.org/10.1177/0263774X18806508

Cowley, R., Joss, S., \& Dayot, Y. (2018). The smart city and its publics Q: insights UK cities. Urban Research \& Practice, 11(1), 5377. https://doi.org/10.1080/17535069.2017.1293150

Dichter, A. \& Gloria, G.M. (2017). Coping with Success. Managning Destinations (Pdf file). London: McKinsey \& Company and World Travel \& Tourism Council. Retrieved from https://www.wttc.org/-/media/files/reports/policy-research/coping-with-success-managing-overcrowding-in-tourism-destinations-2017.pdf

Dodds R., \& Butler, R. (2019). The enablers of overtourism. In R. Dodds \& R. Butler (Eds.), Overtourism: issues, realities and solutions (pp. 6-21). Boston, MA: De Gruyter Oldenbourg.

Doxey, G.V. (1975). A causation theory of visitor-resident irritants: methodology and research inferences in the impact of tourism. In Sixth Annual Conference Proceedings of the Travel Research Association. San Diego, California.

Dredge, D. (2016). Are DMOs on a path to redundancy? Tourism Recreation Research, 41(3), 348-353. https://doi.org/10.1080/02508281.2016.119595

Eckert, C., Zacher, D., Pechlaner, H., Namberger, P., \& Schmude, J. (2019). Strategies and measures directed towards overtourism: a perspective of European DMOs. International Journal of Tourism Cities. https://doi.org/10.1108/IJTC-12-2018-0102

European Cities Marketing. (2018). Managing Tourism Growth in Europe. The ECM Toolbox, 30. Retrieved from https://fr.calameo.com/read/0006740147d7bd41b5afc 
EXCELTUR (2019). Temas críticos en los destinos turísticos. DIGITUR - Observatorio para la transformación digital de los destinos turísticos (Executive report, phase 1).

Fletcher, R. (2018). Foreword. In C. Milano \& J. A. Mansilla (Coords.), Ciudad de vacaciones: conflictos urbanos en espacios turísticos (pp. 9-18). Barcelona: Pol.len.

Fomento de San Sebastián (2015). Donostia San Sebastián Smart Plan 2016-2020 (Plan Summary). Retrieved from

http://www.fomentosansebastian.eus/images/sectores_emergentes/smartenergy/plan_smart/PLAN_SMART_DONOSTIA_EN.pdf

Francis, J. (2019). Foreword. In R. Dodds \& R. Butler (Eds.), Overtourism: issues, realities and solutions (pp. I-II). Boston, MA: De Gruyter Oldenbourg

García Hernández, M., Calle Vaquero, M. de la, \& Yubero Bernabé, C. (2017). Cultural Heritage and Urban Tourism: Historic City Centres under Pressure. Sustaninability, 9, 1346. 2071-1050. https://doi.org/10.3390/su9081346

Giffinger, R., Fertner, C., Kramar, H., Kalasek, R., Pichler-Milanovic, N., \& Meijers, E. (2007). Smart cities: Ranking of European medium-sized cities. Retrieved from: http://www.smartcities.eu/download/smart_cities_final_report.pdf

Gil, J., \& Sequera, J. (2018). Expansión de la ciudad turística y nuevas resistencias. El caso de Airbnb en Madrid. EMPIRIA. Revista de Metodología de Ciencias Sociales, 41, 1532. https://doi.org/empiria.41.2018.22602

Goodwin, H. (2017). The challenge of overtourism. Responsible Tourism Partnership (Working Paper 1). Retrieved from

https://haroldgoodwin.info/pubs/RTP\%27WP4Overtourism01\%272017.pdf

Greenfield, A. (2013). Against the smart city. New York (USA): Do Projects.

Gretzel, U. (2018). From smart destinations to smart tourism regions. Investigaciones RegionalesJournal of Regional Research, 42, 171-184.

Gretzel, U., Werthner, H., Koo, C., \& Lamsfus, C. (2015). Conceptual foundations for understanding smart tourism ecosystems. Computers in Human Behavior, 50, 558563. https://doi.org/10.1016/j.chb.2015.03.043 
Hall, C. M. (2019). Constructing sustainable tourism development: The 2030 agenda and the managerial ecology of sustainable tourism. Journal of Sustainable Tourism, 27(7), 10441060. https://doi.org/10.1080/09669582.2018.1560456

Hollands, R. G. (2008). Will the real smart city please stand up? City, 12(3), 303320. https://doi.org/10.1080/13604810802479126

Huete, R., \& Mantecón, A. (2018). El auge de la turismofobia chipótesis de investigación o ruido ideológico? PASOS Revista de Turismo y Patrimonio Cultural, 16(1), 919. https://doi.org/10.25145/j.pasos.2018.16.001.

IBM (2010). A vision of smarter cities: How cities can lead the way into a prosperous and sustainable future. New York: IBM Institute for Business Value. Retrieved from https://www03.ibm.com/press/attachments/IBV_Smarter_Cities___Final.pdf

INE (2019). Encuesta de ocupación hotelera.

http://ine.es/dyngs/INEbase/es/operacion.htm?c=Estadistica_C\&cid=1254736177015\&menu =ultiDatos\&idp=1254735576863.

Ivars-Baidal, J. A., Celdrán-Bernabeu, M. A., Mazón, J.-N., \& Perles-lvars, Á. F. (2017). Smart destinations and the evolution of ICTs: a new scenario for destination management? Current Issues in Tourism, 1581-1600. https://doi.org/10.1080/13683500.2017.1388771.

Joppe, M. (2019). The roles of policy, planning and governance in preventing and managing overtourism. En R. Dodds \& R. Butler (Eds.), Overtourism: issues, realities and solutions (pp. 250-261). Boston, MA: De Gruyter Oldenbourg.

Koens, K., Postma, A., \& Papp, B. (2018). Is overtourism overused? Understanding the impact of tourism in a city context. Sustainability (Switzerland), 10(12), 1-

\section{5. https://doi.org/10.3390/su10124384}

Kitchin, R. (2015). Making sense of smart cities: addressing present shortcomings. Cambridge Journal of Regions, Economy and Society, 8(1), 131136. https://doi.org/10.1093/cjres/rsu027

Komninos, N. (2015). The age of intelligent cities: smart environments and innovation-for-all strategies (First Edition). New York: Routledge, Taylor \& Francis Group.

López Palomeque, F. (2015). Barcelona, de ciudad con turismo a ciudad turística. Notas sobre un proceso complejo e inacabado. Documents d'Anàlisi Geogràfica, 61(3), 483506. https://doi.org/10.5565/rev/dag.296 
March, H., \& Ribera-Fumaz, R. (2016). Smart contradictions: The politics of making Barcelona a Self-sufficient city. European Urban and Regional Studies, 23(4), 816830. https://doi.org/10.1177/0969776414554488

Marín Cots, P. (2017). Sostenibilidad urbana en la ciudad turística, simbología, simulación y masificación (Doctoral thesis, Universidad de Málaga, Spain) (Unpublished).

Mathieson, A., \& Wall, G. (1982). Tourism: economic, physical, and social impacts. London, New York: Longman

Merricks White, J. (2019). Politicising smart cities standards. In C. Coletta, L. Evans, L. Heaphy, \& R. Kitchin (Eds.), Creating smart cities (pp. 33-48). Abingdon, Oxon, New York, NY: Routledge.

Milano, C. (2018). Overtourism, malestar social y turismofobia. Un debate controvertido. PASOS Revista de Turismo y Patrimonio Cultural, 16(3), 551564. https://doi.org/10.25145/j.pasos.2018.16.041.

Milano, C., \& Mansilla, J. A. (Coord.) (2018). Ciudad de vacaciones: conflictos urbanos en espacios turísticos. Barcelona: Pol.len.

Milano, C., Novelli, M., \& Cheer, J. M. (2018). Overtourism and Tourismphobia through four decades of tourism development, planning and local concerns. Tourism Planning and Development Journal. https://doi.org/10.1080/21568316.2019.1599604

Muñoz González, F.J. (2016). Actitudes de los residentes hacia los impactos del turismo: el caso de Málaga capital como destino turístico cultural (Doctoral thesis, Universidad de Málaga, Spain) (Unpublished).

Navarro-Jurado, E., Romero-Padilla, Y., Romero-Martínez, J. M., Serrano-Muñoz, E., Habegger, S., \& Mora-Esteban, R. (2018). Crecimiento turístico y expulsión de ciudadanía: un análisis desde los movimientos sociales de la gestión turística en la ciudad de Málaga. In De lugar geográfico a destino turístico: análisis, planificación y gestión de los procesos de cambio generados por el turismo (pp. 123-134). León: Universidad de León.

Navarro-Ruiz, S., Casado-Díaz, A. B., \& Ivars-Baidal, J. (2019). Cruise tourism: the role of shore excursions in the overcrowding of cities. International Journal of Tourism Cities. https://doi.org/10.1108/IJTC-04-2018-0029

OECD. (2018). OECD Tourism Trends and Policies 2016. OECD Tourism Trends and Policies 2018. https://doi.org/10.1787/tour-2012-en 
O'Reilly, A. M. (1986). Tourism carrying capacity: Concept and issues. Tourism Management, 7(4), 254-258. https://doi.org/https://doi.org/10.1016/0261-5177(86)90035-X.

Peeters, P., Gossling, S., Klijs, J., Milano, C., Novelli, M., Dijkmans, C., \& Postma, A. (2018). Research for TRAN Committee - Overtourism: impact and possible policy responses, European Parliament, Policy Department for Structural and Cohesion Policies (October). Retrieved from http://www.europarl.europa.eu/thinktank/en/document.html?reference=IPOL STU(2018) $\underline{629184}$

Russo, A.P., \& Scarnato, A. (2017). Barcelona in common': a new urban regime for the 21stcentury tourist city? Journal of Urban Affairs, 40(4), 455-474.

https://doi.org/10.1080/07352166.2017.1373023

Sequera, J. \& Gil, J. (2018). Resistencias contra la ciudad turística. Airbnb en Madrid. In C. Milano \& J. A. Mansilla (Coord.) (2018). Ciudad de vacaciones: conflictos urbanos en espacios turísticos (pp.189-222). Barcelona: Pol.len,

Torres Mora, L. (2018). Turismofobia y turistificación en el Barri del Carme (Doctoral thesis, Universidad de Valencia, Spain) (Unpublished).

Townsend, A. M. (2013). Smart cities: big data, civic hackers, and the quest for a new utopia. New York: Company.

Tuan, Y.F. (1977). Space and place. The Perspective of Experience. Minneapolis: University of Minnesota.

Turisme Comunitat Valenciana \& CERCLE (2019). Afrontando los retos del overtourism en destinos patrimoniales y naturales a través de Open/Big Data. Generalitat Valenciana. Proyecto Herit Data. Retrieved from

https://www.turisme.gva.es/opencms/opencms/turisme/es/contents/planificacion/heritdata/ HD Informe_ejecutivo_BENCHMARKING.pdf

Turismo de San Sebastián (2017). Plan de Turismo Donostia San Sebastián 2017-2020. Retrieved from https://press.sansebastianturismoa.eus/images/prensa_agentes/pdf/NisitBizi_Memoria_completo_Cast.pdf

Turismo Valencia (2017). València turística, hacia 2020. Retrieved from https://www.visitvalencia.com/sites/default/files/pdfs/fundacion/plan-actuaciones-20172020.pdf 
UNWTO (2018). 'Overtourism'? - Understanding and Managing Urban Tourism Growth beyond Perceptions. World Tourism Organization (UNWTO), Centre of Expertise Leisure, Tourism \& Hospitality, NHTV Breda University of Applied Sciences, and NHL Stenden University of Applied Sciences. Madrid: UNWTO. https://doi.org/10.18111/9789284419999

Vanolo, A. (2014). Smartmentality: The Smart City as Disciplinary Strategy. Urban Studies, 51(5), 883-898. https://doi.org/10.1177/0042098013494427.

Yeoman I. (2018): Future driving forces of city tourism in the tourism market. In UNWTO: 'Overtourism'? - Understanding and Managing Urban Tourism Growth beyond Perceptions, Executive Summary (pp 44-46). https://doi.org/10.18111/9789284420070 